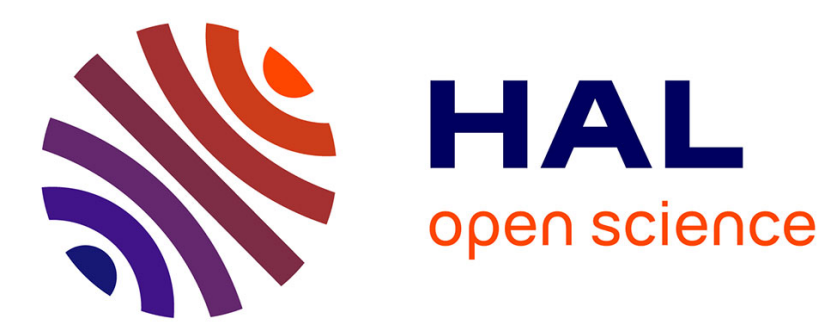

\title{
Optimal Monetary Provisions in Plural Form Franchise Systems; A Theoretical Model of Incentives with Two Risk-Averse Agents
}

Cintya Lanchimba

\section{- To cite this version:}

Cintya Lanchimba. Optimal Monetary Provisions in Plural Form Franchise Systems; A Theoretical Model of Incentives with Two Risk-Averse Agents. 2013. halshs-00830899

\section{HAL Id: halshs-00830899 \\ https://shs.hal.science/halshs-00830899}

Preprint submitted on 6 Jun 2013

HAL is a multi-disciplinary open access archive for the deposit and dissemination of scientific research documents, whether they are published or not. The documents may come from teaching and research institutions in France or abroad, or from public or private research centers.
L'archive ouverte pluridisciplinaire HAL, est destinée au dépôt et à la diffusion de documents scientifiques de niveau recherche, publiés ou non, émanant des établissements d'enseignement et de recherche français ou étrangers, des laboratoires publics ou privés. 
Optimal Monetary Provisions in Plural Form Franchise Systems ; A Theoretical Model of Incentives with Two RiskAverse Agents 


\section{GATE Groupe d'Analyse et de Théorie Économique Lyon-St Étienne}

93, chemin des Mouilles 69130 Ecully - France

Tel. +33(0)4 72866060

Fax $+33(0) 472866090$

6, rue Basse des Rives 42023 Saint-Etienne cedex 02 - France

Tel. +33 (0)4 77421960

Fax. +33 (0)4 77421950

Messagerie électronique / Email : gate@gate.cnrs.fr

Téléchargement / Download : http://www.gate.cnrs.fr - Publications / Working Papers 


\title{
Optimal Monetary Provisions in Plural Form Franchise Systems; A Theoretical Model of Incentives with Two Risk-Averse Agents
}

\author{
Cintya Lanchimba* \\ Université de Lyon, Lyon, F-69007, France \\ CNRS, GATE Lyon-St Etienne, UMR n 5824, 69130, Ecully, France \\ Université de Saint-Etienne, Jean Monnet, F-42023 Saint-Etienne, France \\ cintya.lanchimba@univ-st-etienne.fr
}

June 5, 2013

\begin{abstract}
Empirical studies show that most franchise chains use dual distribution - or a plural form franchise system - characterized by the coexistence of franchised units and companyowned retail units in the same distribution network. Therefore, this paper focuses on dual distribution and considers the different contractual arrangements in this type of franchise system. The paper contributes to the theoretical efforts at developing a model to study the optimal determination of the share parameters (commission and royalty rates) in a mixed system.
\end{abstract}

\section{Keywords:}

Dual distribution, royalty rate, commission rate, risk aversion, moral hazard.

JEL codes:

L14, D82

*I am grateful to M. Fadairo, J. Windsperger, P. Billand, C. Bravard and B. Montmartin for their helpful comments. This research has received funding from the National Secretary of Higher Education, Science, Technology and Innovation of Ecuador. 


\section{Introduction}

Franchising is one of the most popular business practices. The rise of this type of distribution network is a global phenomenon that affects numerous countries. Thus, according to the European Federation of Franchise, franchised brands increased by $20 \%$ between 2007 and 2009 in France, $4 \%$ in the UK and $5 \%$ in Germany, with major implications in terms of employment.

More specifically, Germany had 980 established franchise networks with 65500 franchisees, representing $€ 55$ billion Euros in turnover, which generated 463000 jobs in 2010. Furthermore, in 2010 the United Kingdom had 842 franchisors and 34800 franchisees, which represented $€ 15.20$ billion Euros in turnover and generated 462000 jobs. Lastly, France had 1569 franchisors and 62041 franchisees producing $€ 49.24$ billion Euros in turnover that generated 310265 jobs in 2011 (French Franchising Federation, 2012).

Moreover, between 2011 and 2012, the US franchised sector employed approximately 18 million people, in turn generating an economic output of over 2.1 trillion, equal to approximately $40.9 \%$ of the retailing sector, and contributed $4.8 \%$ of GDP growth, $5 \%$ to sales growth and $2.1 \%$ to employment growth (PricewaterhouseCoopers, 2011).

Between 2009 and 2010, the Brazilian franchised sector increased sales by 20\%, employment by $7.9 \%$ and the number of networks by $12.9 \%$ (Brazilian Franchise Association, 2010). According to the U.S. Commercial Service, Venezuela ranks third in Latin America with respect to franchising, after Brazil and Mexico. Annual growth in franchising growth is estimated to be $25 \%$ (number of outlets) and the sector's contribution to non-petroleum GDP is estimated to be $2.2 \%$ in 2007, with an increase to $2.9 \%$ in 2011 (Front Consulting Group and Cámara Venezolana de Franquicias-Profranquicias, 2011). Franchising in Mexico, however, grew by $14 \%$ in 2008, when the World Franchise Council ranked Mexico as the 7th leading nation in franchise development (The U.S. Commercial Service (2009)). In addition, franchising in Mexico grew $13 \%$ in 2011; Mexico has 1013 franchises, turnover is nearly 85 billion Mexican pesos annually, which is represents 500000 jobs (Mexican Association of Franchises (2012)).

Therefore, franchise networks are very dynamic and present worldwide, and this study should, therefore, receive particular attention from researchers.

The economic analysis in this paper, based on the theoretical foundations of Rey and Tirole (1986), analyzes franchises as a contractual innovation that faces informational problems, externalities and coordination problems (vertical and horizontal). Economic theory focuses on the characteristics of contractual agreements (vertical restrictions) between producers and retailers (duration of contracts, royalty rates, territorial exclusivity, contributions to investments, etc.), the aim being to explain their presence in real economic contracts and provide normative approach to determine the optimal contractual structure to yield greater efficiency.

The theories of industrial organization are used to understand this phenomenon. Thus, the studies employing the agency theory framework focus on the problems associated with providing the proper incentives to elicit effort in the franchise relationship (Vázquez, 2005). Studies employing the perspective of transaction costs theory analyze franchises as a hybrid form between vertical integration and conventional contracts, showing that it is effective in the presence of specific assets, such as a common brand name throughout the network (Lafontaine and Slade, 2010).

While economists focus on contractual terms, management science researchers are often interested in the organizational designs of the networks.

Given the success of certain organizational forms in distribution networks, particularly in franchising, management science researchers, especially marketing researchers, expressed early interest in the subject. Franchise was then considered to be a temporary organizational form, 
making it possible to relax financial and human constraints because the franchisee is an investor and an entrepreneur. Early versions of "scarcity theory" were developed by Hunt (1973) and Oxenfeldt and Kelly (1968).

The focus of franchise studies then turned to the study of mixed networks where franchised units and company-owned retail units coexist. Thus, "tapered integration theory" (Harrigan, 1984) supports the notion of mixing in networks, and Bradach (1997), in his exploratory study, highlights the synergies between franchised units and owned units. Lastly, contributions employing property rights theory included the shared decision rights between the franchisor and franchisee and how they related to individual knowledge (Dant and Windsperger, 2006).

The empirical literature on franchising emphasizes the relevance of contract theory to understanding this major phenomenon. The relationships between franchisors and franchisees are characterized by information asymmetries, and the mechanisms included in franchise contracts can be understood as a means of addressing these asymmetries.

A survey of the literature ${ }^{1}$ in the fields of economics and management shows that 124 papers were devoted to franchising over the period 2000-2012; 99 of which were empirical papers. From this empirical literature on franchising, two major theoretical frameworks emerge: theories of contracts and resource scarcity theory, as shown in Table 1.

\begin{tabular}{|c|c||c|c|}
\hline Theoretical framework & $\begin{array}{c}\text { Number of related } \\
\text { articles }\end{array}$ & Theoretical framework & $\begin{array}{c}\text { Number of related } \\
\text { articles }\end{array}$ \\
\hline \hline Theories of contracts & 48 & Theory of incentives & 40 \\
\hline Resource Scarcity Theory & 21 & Transaction Costs Theory & 7 \\
\hline Other & 22 & Signaling Theory & 1 \\
\hline Not mentioned & 8 & $\begin{array}{c}\text { Total number of } \\
\text { empirical papers } \\
\text { on franchising in } \\
\text { the contract theory }\end{array}$ & 48 \\
$\begin{array}{c}\text { Total number of } \\
\text { on franchichising* }\end{array}$ & 99 & \\
\hline
\end{tabular}

Table 1: Theoretical frameworks in the literature on franchise data.

*From a survey of 23 top ranked reviews in Economics and Management over the period 2000-2012.

In this literature, only 19 papers were theoretical studies concerning private information (Hempelmann B., 2005), dual distribution (Bai C. and Tao Z., 2000) or territorial exclusivity (Nair S., Tikoo S. and Liu S., 2009). Here again, agency theory is the main framework (7 papers), followed by the game theory (5 papers).

In summary, in recent decades, agency-theoretic explanations in terms of moral-hazards, incentive problems and monitoring costs were the dominant direction in empirical franchising research (e.g., Alon, 2000; Lafontaine and Shaw, 2005; Castrogiovanni et al., 2006; Pénard et al., 2011). Thus, agency theory appears to have been the most widely applied theory to explain franchising. However, theoretical analysis employing the agency framework remain limited, with only 7 theoretical papers over the last twelve years (Bai and Tao, 2000; Lewis, 2002; Hemplemann, 2006; Tracey and Jarvis, 2007; Etro, 2011; Hendrikse, 2011; Chirico et al., 2011).

\footnotetext{
${ }^{1}$ This survey considers the 22 top ranked reviews journals in Economics and Management over the past twelve years. The journals considered here are presented in alphabetical order: Academy of Management Journal, American Economic Review, Applied Economics, Entrepreneurship Theory and Practice, European Economic Review, European Management Review, International Journal of Industrial Organization, Journal of Business Venturing, Journal of Economic Perspectives, Journal of Economics and Management Strategy, Journal of Industrial Economics, Journal of Law and Economics, Journal of Law, Economics and Organization, Journal of Marketing, Journal of Marketing Channels, Journal of Marketing Research, Journal of Retailing, Journal of Small Business Management, Journal of the Academy of Marketing Science, Marketing Science, Quarterly Journal of Economics, RAND Journal of Economics, Review of Industrial Organization.
} 
Using the framework of agency theory, the aim of this paper is to study monetary clauses (the royalty rate and commission rate) as incentive devices in mixed distribution networks, in other words, in franchising networks using dual distribution.

Dual distribution is common in franchise systems worldwide. Thus, in Brazil, France, US and Venezuela, over $65 \%$ of franchise networks employ dual distribution (see Table 2). Therefore, studying this phenomenon appears crucial to better understand franchising.

\begin{tabular}{|c|c|c|c|c|}
\hline Country* & $\begin{array}{c}\text { Number of } \\
\text { Networks }\end{array}$ & $\begin{array}{c}\text { Only Franchised } \\
\text { Units }\end{array}$ & $\begin{array}{c}\text { Only Owned } \\
\text { Units }\end{array}$ & $\begin{array}{c}\text { Dual } \\
\text { Distribution }\end{array}$ \\
\hline \hline $\begin{array}{c}\text { Brazil } \\
(2012)\end{array}$ & 202 & $17 \%$ & $6 \%$ & $77 \%$ \\
\hline $\begin{array}{c}\text { France } \\
(2007)\end{array}$ & 307 & $30 \%$ & $5 \%$ & $65 \%$ \\
\hline $\begin{array}{c}\text { Venezuela } \\
(2012)\end{array}$ & 217 & $13 \%$ & $20 \%$ & $67 \%$ \\
\hline $\begin{array}{c}\text { Unites States } \\
(2012)\end{array}$ & 94 & $16 \%$ & $10 \%$ & $74 \%$ \\
\hline
\end{tabular}

Table 2: Dual Distribution.

From: Brazilian Franchise Association (2012), INSEE (2007), Front Consulting Group and Cámara Venezolana de FranquiciasProfranquicias (2012) and Bond's guide (2012).

*These data are unavailable for Mexico

Before proceeding with the analysis, the theoretical literature on dual distribution should be reviewed. Gallini, N. and Lutz, N. (1992) developed a seminal model of signaling, formally demonstrating that the "good type" of franchisors can signal their type and therefore provide relevant information to the future franchisees. The signaling devices take organizational and contractual forms that make the franchisor's revenue highly dependent on the profitability of the business concept.

In addition, Bai and Tao (2000) use the agency framework to study dual distribution by adapting the Holmstrom and Milgrom (1991) multitasking model. These authors emphasize the complementarities between company-owned units and independent retailers coexisting in the same network. In dual distribution, each type of downstream unit is devoted to a specific task; owned units are more involved in the promotion of the common brand, while franchised units are more involved in sales efforts.

Moreover, using a risk-theoretic model, Bürkle, T. and Posselt, T. (2008) study a plural form franchise system to explain the proportion of franchisees relative to the company-owned outlets in the chain. They show that the incentive to franchise decreases as the share of franchiseeowned selling units increases, as well as with decreasing control costs. In addition, Hendrikse and Jiang (2011) find that the efficiency of dual distribution as a governance mechanism does not depend on heterogeneous downstream outlets.

Second, two theoretical papers, using the agency theory framework, address the determination of royalty rates in pure franchise systems. Bhattacharyya and Lafontaine (1995) highlight the double-sided moral hazard in the franchise relationship and determine the optimal royalty rate in a linear contract, finding that the optimal share parameter will be independent of the scale of operations and the cost of effort for the two parties to the contract. Subsequently, Brickley J. (2002) employs a theoretical and an empirical model to study the effects of termination laws in franchise contracts, providing evidence regarding the determinants of royalties and upfront fees in share contracts.

The aim of this paper is to combine these two strands of the literature. This study proceeds as follows: Section 2 presents a theoretical agency model of monetary provision in the case of 
dual distribution. The franchisor is studied as the principal of a distribution chain with two agents: a franchisee and the manager of a company-owned retail unit. A general description of the model is provided, and three distinct cases regarding the informational context are studied. Section 3 discusses the results and presents seven propositions. Section 4 concludes.

\section{The Model}

This model considers plural form franchising systems, where company-owned downstream units coexist with franchised outlets. As mentioned above, most franchise networks combine the two types of downstream units (see Table 2).

The aim of this moral-hazard model is to define the contractual design, more precisely the monetary terms, while maximizing the franchisor's profit, under the assumption that there are two different types of agents: a franchisee and the manager of a company-owned outlet.

The model is based on prior studies in the theoretical literature on franchising: Bhattacharyya S. and Lafontaine F. (1995), Lafontaine F. and Slade M. (1998), Lafontaine F. and Blair R. (2005), Bürkle T. and Posselt T. (2008), Milgrom P. and Roberts J. (1992), Bai, C. and Tao, Z. (2000).

Because plural form networks combine two types of agents (the downstream outlets), the principal (the franchisor) cannot employ a single strategy for the two different types of agents. The franchisees are rewarded with downstream profits, while the managers of company-owned units are compensated with wages (see Figure 1).

On the one hand, the standard principal-agent model introduces the notion of risk-aversion, i.e., the agent or the principal "values income levels that he knows he will obtain with certainty above the same income level obtained in expectation only" (Lafontaine 2005 pg.109). This formulation of expected utility is known as a Von Neumann-Morgenstern type function.

First, for simplicity, we assume that the network has only one franchisee and one manager. Assuming that the manager is only rewarded with a fixed wage, he will not necessarily be encouraged to exert his maximal effort. We therefore assume that manager compensation contains a fixed component (the wage) and a variable component that depends on the sales of the company-owned unit (commission rate). Second, we assume that an inverse relationship exists between the upfront fee and royalty rate. That is, this relationship depends on franchisor risk aversion; if he is less risk averse, he will prefer the up-front fee. Third, we assume that the franchisor, the manager and the franchisee are risk averse. Fourth, to simplify the analysis, we assume that the product price is exogenously given. However, the contracting parties influence demand in a sales area via their effort. 


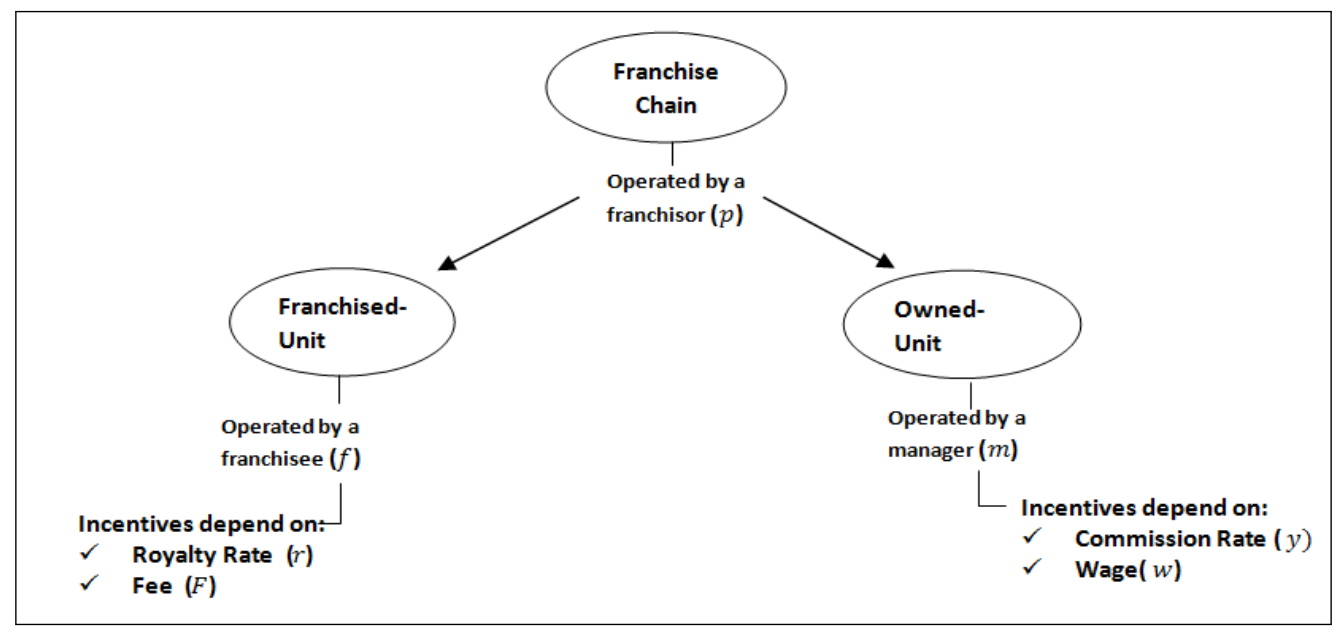

Figure 1: Overview of the model

In summary, we assume that:

Assumption 2.1. The network contains a franchised-unit and a company owned-unit.

Assumption 2.2. The franchisee is remunerated with the profits from his own unit.

Assumption 2.3. Manager compensation is composed of a fixed component $(w)$ and a commission $(y)$ that varies depending on his sales in the downstream market.

Assumption 2.4. The franchisor obtains revenue from each downstream unit.

Assumption 2.5. The franchisor's effort is applied is to promote the network.

Assumption 2.6. An inverse relationship exists between the up-front fee and the royalty rate.

Assumption 2.7. The franchisor, the franchisee and the manager are risk averse.

Assumption 2.8. The cost of effort is the only operating cost in the franchise network.

Assumption 2.9. The franchised-unit and the company-owned unit are local monopolies, i.e. franchisee has a territorial exclusivity.

Assumption 2.10. The contracting parties do not influence demand though the price of good (l) (Hemplemann, B. (2006)).

\subsection{General Description}

In contract theory, the utility function for an agent with constant risk aversion $(C A R A)$ is frequently defined as: $u(I)=-\exp (-\rho I)$, where $I$ represents income and $\rho$ is the coefficient of absolute risk aversion; in this type of utility function, the agent behaves as if he is maximizing his certainty-equivalent income, $C E$, defined as:

$$
C E=E(I)-R
$$

The certainty-equivalent income is the quantity that remains once the risk premium is paid. Let $E(I)$ denote the income expectation operator and $R$ risk aversion. Thus, the expected profit for the franchisor, the franchisee and the manager are, respectively ${ }^{2}$.

\footnotetext{
${ }^{2}$ The subscripts $\rho, f$ and $m$ refer to the franchisor, franchisee and manager, respectively.
} 


$$
\begin{gathered}
E\left(I_{p}\right)=r h\left(e_{f}, e_{p}\right) l+(1-y) h\left(e_{m}, e_{p}\right) l+F-C\left(e_{p}\right)-w \\
E\left(I_{f}\right)=(1-r) h\left(e_{f}, e_{p}\right) l-F-C\left(e_{f}\right) \\
E\left(I_{m}\right)=w+y h\left(e_{m}, e_{p}\right) l+C\left(e_{m}\right)
\end{gathered}
$$

where,

$$
\begin{array}{ll}
r= & \text { royalty rate } \\
e_{.}= & \text {effort } \\
h\left(e_{f}, e_{p}\right)= & \text { final demand to the franchised-unit } \\
l= & \text { price of good } \\
y= & \text { commission rate paid by the franchisor to the manager } \\
F= & \text { up-front fee } \\
C\left(e_{.}\right)= & \text {cost of effort } \\
w= & \text { manager's wage } \\
h\left(e_{m}, e_{p}\right)= & \text { final demand to the company-owned unit }
\end{array}
$$

We assume that the two agents (franchisee, manager) and the principal are CARA, and hence the risk premium is defined by the following:

$$
R=\frac{\rho}{2} \operatorname{Var}(I)
$$

The risk premium associated with the random income is the amount that an individual is willing ${ }^{3}$ to pay in order to make the switch between an income and a random income with an expect. In others words, it is the difference between the expected payoff and the certainty equivalent, where $\rho$ is the coefficient of aversion and $\operatorname{Var}(I)$ refers to the variance. Thus, the risk premium for the franchisor, manager and franchisee are defined as follows:

$$
\begin{gathered}
R_{p}=\frac{\rho_{p}}{2} \operatorname{Var}\left(r \theta_{f}+(1-y) \theta_{m}\right) \\
R_{f}=\frac{\rho_{f}}{2} \operatorname{Var}\left((1-r) \theta_{f}\right) \\
R_{m}=\frac{\rho_{m}}{2} \operatorname{Var}\left(y \theta_{m}\right)
\end{gathered}
$$

The risk premium accounts the coefficient of risk aversion $\rho$ and the variation in income. That is, the risk premium associated with the franchisee is the percentage of revenues he receives $(1-r)$, and the variance in sales $\left(\theta_{f}\right)$, or the state of nature. The manager's risk premium captures the percentage of revenues he receives $(y)$ and the variance in sales $\left(\theta_{m}\right)$, or the state of nature. Lastly, the franchisor's risk premium $(r,(1-y))$ uses the two percentages that he receives and the variance in sales, or the state of nature.

Using equations (2.2, 2.3 and 2.2) and (2.6, 2.7 and 2.8), we can rewrite the certainty equivalents of the two agents and the principal as:

\footnotetext{
${ }^{3}$ The theoretical risk premium would be the lowest likelihood payoff paying a price for the risk and would be based on the calculation of probabilities of the outcomes in question.
} 


$$
\begin{aligned}
C E_{p}= & r h\left(e_{f}, e_{p}\right) l+(1-y) h\left(e_{m} f, e_{p}\right) l+F-C\left(e_{p}\right)-w \\
& -\frac{\rho_{p}}{2}\left(\operatorname{Var}\left(r \theta_{f}\right)+\operatorname{Var}(1-y) \theta_{m}+2 \operatorname{Cov}(r,(1-y))\right.
\end{aligned}
$$

First, the franchisor's certainty equivalent $C E_{p}$ is divided into three components. The first is the income provided by the franchisee $\left(r h\left(e_{f}, e_{p}\right) l+F\right)$, while the second is that provided by the manager $\left((1-y) h\left(e_{m} f, e_{p}\right) l\right)$. Note that each of these two components depends on the effort of the franchisee $h\left(e_{f}, e_{p}\right)$, the manager $h\left(e_{m}, e_{p}\right)$ and the franchisor. The third component is the cost that the franchisor must pay. This cost refers to: the cost of his own effort $C\left(e_{p}\right)$, the wage paid to the manager $\left(w+y h\left(e_{m}, e_{p}\right) l\right)$ and the risk premium.

$$
C E_{f}=(1-r) h\left(e_{f}, e_{p}\right) l-F-C\left(e_{f}\right)-\frac{\rho_{f}}{2}(1-r)^{2} \theta_{f}^{2}
$$

Second, the franchisee's certainty equivalent $C E_{f}$ is defined as his income when royalties $(r)$ are paid to the franchisor, minus the up-front fee $F$, the cost of his effort $C\left(e_{f}\right)$ and the risk premium.

$$
C E_{m}=w+y h\left(e_{m}, e_{p}\right) l-C\left(e_{m}\right)-\frac{\rho_{m}}{2} y^{2} \theta_{m}^{2}
$$

Lastly, the manager's certainty equivalent $C E_{m}$ is his wage plus commission $(y)$ over sales minus the cost of his effort $C\left(e_{m}\right)$ and the risk premium.

We assume that the demand function satisfies ${ }^{4}$ :

Assumption 2.11. $d h / d e_{m}\left(e_{m}, e_{p}\right)>0, d h / d e_{f}\left(e_{f}, e_{p}\right)>0, d h / d e_{p}\left(e_{p}, e\right)>0$,

$$
d^{2} h / d e_{f}^{2}\left(e_{f}, e_{p}\right)<0, d^{2} h / d e_{p}^{2}\left(e_{f}, e_{p}\right)<0, d^{2} h / d e_{m}^{2}\left(e_{m}, e_{p}\right)<0
$$

The demand function exhibits positive but decreasing or increasing returns to effort.

Assumption 2.12. $d^{2} h / d e_{f} d e_{p}\left(e_{f}, e_{p}\right)=0, d^{2} h / d e_{p} d e_{m}\left(e_{p}, e_{m}\right)=0$

The parties influence demand independently.

Assumption 2.13. $\lim _{e_{f} \rightarrow 0} d h / d e_{f}\left(e_{p}, e_{f}\right)=\infty, \lim _{e_{p} \rightarrow 0} d h / d e_{p}\left(e_{p}, e_{f}\right)=\infty$, $\lim _{e_{m} \rightarrow 0} d h / d e_{f}\left(e_{p}, e_{m}\right)=\infty, \lim _{e_{p} \rightarrow 0} d h / d e_{f}\left(e_{p}, e_{m}\right)=\infty$

Assumption 2.14. $\lim _{e_{f} \rightarrow \infty} d h / d e_{f}\left(e_{p}, e_{f}\right)=0, \lim _{e_{p} \rightarrow \infty} d h / d e_{p}\left(e_{p}, e_{f}\right)=0$, $\lim _{e_{m} \rightarrow \infty} d h / d e_{f}\left(e_{p}, e_{m}\right)=0, \lim _{e_{p} \rightarrow \infty} d h / d e_{f}\left(e_{p}, e_{m}\right)=0$

Asumption (2.13) and (2.13) exclude the optimality of no or infinite effort expenditures.

We also assume for simplicity that income $l h($.$) is equal to total sales in each network. Thus,$ suppose that a franchisee or a manager must exert effort to generate sales in his outlet, the downstream sales $S^{5}$ will be given by the following:

$$
S=\alpha e+\varepsilon \quad \sim \quad N\left(0, \theta^{2}\right)
$$

\footnotetext{
${ }^{4}$ For additional information regarding this assumption, see Hemplemann, B. (2006)

${ }^{5}$ For further information regarding this expression, see Lafontaine F. and Blair R. (2005)
} 
where $e$ is the manager's effort, $\alpha$ measures the importance of this effort in the sales generation process and $\varepsilon$ is a random variable with mean 0 and variance $\theta^{2}$, which precludes the franchisor from inferring $e$ from observed $S$. When the franchisor and manager, or the franchisee and franchisor, must provide a given level of effort $e$, this effort level is unobservable. This means that the franchisor cannot observe the franchisee's or the manager's effort, and the franchisor's advertising effort cannot be observed by the agents. Therefore, the optimal contract will involve revenue sharing. Thus, the franchisee's sales and the manager's sales will be given by the following:

$$
S_{f}=\alpha e_{f}+\frac{\delta e_{p}}{2}+\varepsilon_{f} \quad \sim \quad N\left(0, \theta_{f}^{2}\right)
$$

The income generated by the franchised-unit is the sum of the franchisee's effort $e_{f}$, the importance of this effort $\alpha$, the franchisor's effort $e_{p}$ and his importance $\delta$ in the sales process.

$$
S_{m}=\beta e_{m}+\frac{\delta e_{p}}{2}+\varepsilon_{m} \quad \sim \quad N\left(0, \theta_{m}^{2}\right)
$$

In this sense, the income generated by the owned-unit is the sum of franchisee effort $e_{m}$, the importance of this effort $\beta$, the franchisor's effort $e_{p}$ and his importance $\delta$ in the sales process.

The franchisor's effort has identical effects on the franchisee's sales and the manager's sales. For this reason, we divide the principal's cost of effort so as not to duplicate the principal's effort $e_{p}$.

We assume that the cost of effort is constant and quadratic, as is frequently defined in the literature $^{6}$ :

$$
C(e)=\frac{e^{2}}{2}=C\left(e_{f}\right)=C\left(e_{m}\right)=C\left(e_{p}\right)
$$

We assume also that there are no other costs associated with operating this business. Using equations (2.6), (2.7), (2.8), (2.13), (2.14) and (2.15), it is possible to rewrite the certainty equivalents for the principal and agents as follows:

$$
\begin{gathered}
C E_{p}=r\left(\alpha e_{f}+\frac{\delta e_{p}}{2}\right)+(1-y)\left(\beta e_{m}+\frac{\delta e_{p}}{2}\right)+F-\frac{e_{p}^{2}}{2}-w \\
-\frac{\rho_{p}}{2}\left(r^{2} \theta_{f}^{2}+(1-y)^{2} \theta_{m}^{2}+2 \operatorname{Cov}\left(\theta_{f} r, \theta_{m}(1-y)\right)\right. \\
C E_{m}=w+y\left(\beta e_{m}+\frac{\delta e_{p}}{2}\right)-\frac{e_{m}^{2}}{2}-\frac{\rho_{m}}{2} y^{2} \theta_{m}^{2} \\
C E_{f}=(1-r)\left(\alpha e_{f}+\frac{\delta e_{p}}{2}\right)-F-\frac{e_{f}^{2}}{2}-\frac{\rho_{f}}{2}(1-r)^{2} \theta_{f}^{2}
\end{gathered}
$$

\subsection{The Franchisor's Problem}

In franchise systems, the franchisor is typically responsible for promoting and advertising the chain. The franchisee and manager, however, are responsible for managing the outlets on a dayto-day basis. The agents' and franchisor's efforts affect the performance of the outlet. However,

\footnotetext{
${ }^{6}$ Lafontaine F. and Blair R., 2005; Lafontaine F. and Slade M., 1998; Milgrom P. and Roberts J., 1992.
} 
the intensity of the effort devoted to such activities is not easily monitored (Bhattacharyya S. and Lafontaine F., 1995). Therefore, the principal's problem can be formalized with the following maximization problem:

$$
\begin{array}{r}
\operatorname{Max}_{\left[r, y, F, w, e_{f}, e_{m}, e_{p}\right]} C E_{p}=r\left(\alpha e_{f}+\frac{\delta e_{p}}{2}\right)+(1-y)\left(\beta e_{m}+\frac{\delta e_{p}}{2}\right)+F-\frac{e_{p}^{2}}{2}-w \\
-\frac{\rho_{p}}{2}\left(r^{2} \theta_{f}^{2}+(1-y)^{2} \theta_{m}^{2}+2 \operatorname{Cov}\left(\theta_{f} r, \theta_{m}(1-y)\right)\right.
\end{array}
$$

s.t.

i. $\quad C E_{m}=w+y\left(\beta e_{m}+\frac{\delta e_{p}}{2}\right)-\frac{e_{m}^{2}}{2}-\frac{\rho_{m}}{2} y^{2} \theta_{m}^{2} \geq U$

ii. $C E_{f}=(1-r)\left(\alpha e_{f}+\frac{\delta e_{p}}{2}\right)-F-\frac{e_{f}^{2}}{2}-\frac{\rho_{f}}{2}(1-r)^{2} \theta_{f}^{2} \geq K$

iii. $\quad \frac{d C E_{p}}{e_{p}}=r \frac{\delta}{2}+(1-y) \frac{\delta}{2}-e_{p}=0$

iv. $\frac{d C E_{f}}{e_{f}}=(1-r) \alpha-e_{f}=0$

v. $\frac{d C E_{m}}{e_{m}}=y \beta-e_{m}=0$

Provided that restrictions (i) and (ii) are satisfied, the manager and franchisee accept the contract. These conditions are known as the participation constraints. Furthermore, the fundamental point of the moral hazard problem is that the principal (and agents) cannot observe the efforts of other actors. Using the first-order approach, the agents (and principal) will select a the level of effort that maximizes his objective function $\left(C E_{(p, m, f)}\right)$. These conditions are known as the incentive constraints ((iii), (iv) and (v) in the franchisor's maximization problem).

\subsection{Case 1: Symmetric information and no relationship between the rates}

We first present the case where the franchisor knows the effort supplied by the agents and the agents know the effort of the franchisor. In this situation, the agents and the principal operate under symmetric information. We assume that the agents and the franchisor are risk averse. Therefore, the franchisor's maximization problem only considers restrictions (i) and (ii). In addition, we assume that the commission rate and the royalty rate are independent. This means that there is no relationship between the two rates; the covariance is 0 .

Consequently, the Lagrangian problem is given by the following:

$$
\begin{array}{r}
\iota=r\left(\alpha e_{f}+\frac{\delta e_{p}}{2}\right)+(1-y)\left(\beta e_{m}+\frac{\delta e_{p}}{2}\right)+F-\frac{e_{p}^{2}}{2}-w \\
-\frac{\rho_{p}}{2}\left(r^{2} \theta_{f}^{2}+(1-y)^{2} \theta_{m}^{2}\right) \\
-\lambda_{1}\left(U+\frac{e_{m}^{2}}{2}+\frac{\rho_{m}}{2} y^{2} \theta_{m}^{2}-w-y\left(\beta e_{m}+\frac{\delta e_{p}}{2}\right)\right) \\
-\lambda_{2}\left(K+F+\frac{e_{f}^{2}}{2}+\frac{\rho_{f}}{2}(1-r)^{2} \theta_{f}^{2}-(1-r)\left(\alpha e_{f}+\frac{\delta e_{p}}{2}\right)\right)
\end{array}
$$

Solving this problem ${ }^{7}$, the royalty rate is defined by the following:

\footnotetext{
${ }^{7}$ See Appendix 2 for details
} 


$$
r^{*}=\frac{\rho_{f} \theta_{f}^{2}}{\rho_{p} \theta_{f}^{2}+\rho_{f} \theta_{f}^{2}}
$$

The commission rate is the following:

$$
y^{*}=\frac{\rho_{p} \theta_{m}^{2}}{\rho_{p} \theta_{m}^{2}+\rho_{m} \theta_{m}^{2}}
$$

Under symmetric information, the coefficient of risk aversion is the only factor that determines the royalty and commission rates.

\subsection{Case 2: Asymmetric information and no relationship between the rates}

We study now the case where the efforts of the agents and principal are unknown. In this situation, the agents and the principal operate under asymmetric information. We assume that the two agents and the franchisor are risk averse. In this case, the franchisor's maximization program considers the four constraints described above. In addition, we assume that the commission and the royalty rates are independent; the covariance is 0 .

Consequently, the Lagrangian problem is given by the following:

$$
\begin{array}{r}
\iota=r\left(\alpha e_{f}+\frac{\delta e_{p}}{2}\right)+(1-y)\left(\beta e_{m}+\frac{\delta e_{p}}{2}\right)+F-\frac{e_{p}^{2}}{2}-w-\frac{\rho_{p}}{2}\left(r^{2} \theta_{f}^{2}+(1-y)^{2} \theta_{m}^{2}\right) \\
-\lambda_{1}\left(U+\frac{e_{m}^{2}}{2}+\frac{\rho_{m}}{2} y^{2} \theta_{m}^{2}-w-y\left(\beta e_{m}+\frac{\delta e_{p}}{2}\right)\right) \\
-\lambda_{2}\left(K+F+\frac{e_{f}^{2}}{2}+\frac{\rho_{f}}{2}(1-r)^{2} \theta_{f}^{2}-(1-r)\left(\alpha e_{f}+\frac{\delta e_{p}}{2}\right)\right) \\
-\lambda_{3}\left(e_{p}-r \frac{\delta}{2}-(1-y) \frac{\delta}{2}\right)-\lambda_{4}\left(e_{f}-(1-r) \alpha\right)-\lambda_{5}\left(e_{m}-y \beta\right)
\end{array}
$$

Solving this problem ${ }^{8}$, the royalty rate is defined as the following:

$$
r^{*}=\frac{4 \rho_{f} \theta_{f}^{2}+\delta^{2} y+\delta^{2}}{4 \rho_{p} \theta_{f}^{2}+4 \rho_{f} \theta_{f}^{2}+4 \alpha^{2}+\delta^{2}}
$$

The commission rate is the following:

$$
y^{*}=\frac{4 \rho_{p} \theta_{m}^{2}+r \delta^{2}-\delta^{2}+4 \beta^{2}}{4 \rho_{p} \theta_{m}^{2}+4 \rho_{m} \theta_{m}^{2}+\delta^{2}+4 \beta^{2}}
$$

Under asymmetric information, in addition to the coefficient of risk aversion, the importance of effort in the downstream sales of each agent determines the royalty and commission rates. Note that the royalty rate is also determined by the commission rate and vice versa, despite the assumption that they are independent.

\footnotetext{
${ }^{8}$ See Appendix 3 for details
} 


\subsection{Case 3: Asymmetric information and the relationship between the rates}

In addition to asymmetric information, we assume now that there is a relationship between the two rates. The covariance ${ }^{9}$ can be re-written as follows:

$$
\operatorname{Cov}\left(\left(\theta_{m}(1-y)\right),\left(\theta_{f} r\right)\right)=\theta_{f} \theta_{m} r(1-y)
$$

We substitute equation (2.26) into (2.19), and the Lagrangian problem is given by the following:

$$
\begin{array}{r}
\iota=r\left(\alpha e_{f}+\frac{\delta e_{p}}{2}\right)+(1-y)\left(\beta e_{m}+\frac{\delta e_{p}}{2}\right)+F-\frac{e_{p}^{2}}{2}-w \\
-\frac{\rho_{p}}{2}\left(r^{2} \theta_{f}^{2}+(1-y)^{2} \theta_{m}^{2}+2 \theta_{f} \theta_{m} r(1-y)\right) \\
-\lambda_{1}\left(U+\frac{e_{m}^{2}}{2}+\frac{\rho_{m}}{2} y^{2} \theta_{m}^{2}-w-y\left(\beta e_{m}+\frac{\delta e_{p}}{2}\right)\right) \\
-\lambda_{2}\left(K+F+\frac{e_{f}^{2}}{2}+\frac{\rho_{f}}{2}(1-r)^{2} \theta_{f}^{2}-(1-r)\left(\alpha e_{f}+\frac{\delta e_{p}}{2}\right)\right) \\
-\lambda_{3}\left(e_{p}-r \frac{\delta}{2}-(1-y) \frac{\delta}{2}\right)-\lambda_{4}\left(e_{f}-(1-r) \alpha\right)-\lambda_{5}\left(e_{m}-y \beta\right)
\end{array}
$$

Solving this problem ${ }^{10}$, the royalty rate is defined as the following:

$$
r^{*}=\frac{4 \rho_{f} \theta_{f}^{2}+\delta^{2} y+\delta^{2}-4 \rho_{p} \theta_{f} \theta_{m}+4 \rho_{p} \theta_{f} \theta_{m} y}{4 \rho_{p} \theta_{f}^{2}+4 \rho_{f} \theta_{f}^{2}+4 \alpha^{2}+\delta^{2}}
$$

The commission rate is the following:

$$
y^{*}=\frac{4 \rho_{p} \theta_{m}^{2}+4 \rho_{p} \theta_{f} \theta_{m} r+r \delta^{2}-\delta^{2}+4 \beta^{2}}{4 \rho_{p} \theta_{m}^{2}+4 \rho_{m} \theta_{m}^{2}+\delta^{2}+4 \beta^{2}}
$$

Under asymmetric information, the royalty rate, the commission rate, the risk aversion coefficient, and the importance of effort in downstream sales determine the royalty and commission rates. However, the royalty rate cannot be determined from equation (2.29) and the commission rate cannot be determined from equation (2.28), as this would result in sub-optimal solutions. Therefore, irrespective of the inclusion of the independence of rates assumption, the factors that determine them remain unchanged.

\section{Results}

The results remain nearly identical irrespective of whether we assume symmetric or asymmetric information (where the rates are independent or dependent). The risk aversion coefficients and the importance of effort in downstream sales determine the optimal royalty and commission rates. In addition, the commission rate is also a parameter in determining the optimal royalty and vice-versa (see Table 3).

\footnotetext{
${ }^{9}$ See Appendix 4 for details

${ }^{10}$ See Appendix 5 for details
} 


\begin{tabular}{|c|c|c|c|}
\hline \multirow{2}{*}{ Variable* } & \multirow{2}{*}{$\begin{array}{l}\text { Symmetric } \\
\text { Information }\end{array}$} & \multicolumn{2}{|c|}{ Asymmetric Information } \\
\hline & & $\begin{array}{c}\text { Independent } \\
\text { Rates }\end{array}$ & $\begin{array}{c}\text { Not independent } \\
\text { Rates }\end{array}$ \\
\hline$\rho_{f} \uparrow$ & $r \uparrow$ & $r \uparrow$ & $r \uparrow$ \\
\hline$\rho_{p} \uparrow$ & $r \downarrow$ & $r \downarrow$ & $r \downarrow$ \\
\hline$\rho_{m} \uparrow$ & $y \downarrow$ & $y \downarrow$ & $y \downarrow$ \\
\hline$\rho_{p} \uparrow$ & $y \uparrow$ & $y \uparrow$ & $y \uparrow$ \\
\hline$\delta \uparrow$ & & $r \uparrow$ & $r \uparrow$ \\
\hline$\delta \uparrow$ & & $y \downarrow$ & $y \downarrow$ \\
\hline$\alpha \uparrow$ & & $r \downarrow$ & $r \downarrow$ \\
\hline$\beta \uparrow$ & & $y \uparrow$ & $y \uparrow$ \\
\hline$r \uparrow$ & & & $y \uparrow \Leftrightarrow(1-y) \downarrow$ \\
\hline
\end{tabular}

Table 3: Summary of the results

*When the variable increases and the other factors remain constant

The following propositions result from the model:

Proposition 3.1. When the franchisee's risk aversion increases, the royalty rate increases.

Proposition 3.2. When the manager's risk aversion increases, the commission rate falls.

Proposition 3.3. When the franchisor's risk aversion increases, the commission rate increases and the royalty rate falls.

The royalty and commission rates act as insurance devices for the agents and principal. Suppose that the franchisor's risk aversion increases. In this situation, the franchisor prefers a safer device to extract the surplus of the franchised unit. Therefore, the franchisor prefers a higher up-front fee rather than a higher royalty rate, as the second device depends on sales.

In addition, to extract income from the owned-unit, the franchisor would prefer to pay a low wage (low constant component and high commission) with a higher commission rate rather than a fixed wage, to force the manager take on the risk.

Now suppose that the franchisee's risk aversion increases. To obtain an insurance mechanism, the franchisee prefers to pay a higher royalty rate and a low up-front fee, as this is a way to share the sales risk with the franchisor. Furthermore, when the manager's risk aversion's increases, he will prefer to be compensated with a higher fixed wage and lower commission, as the final wage would depend little on the sales in the downstream market.

Proposition 3.4. When the importance of the franchisee's effort in downstream sales increases, the royalty rate falls.

Proposition 3.5. When the importance of the manager's effort in downstream sales increases, the commission rate increases.

Proposition 3.6. When the importance of the principal's effort in downstream sales increases, the commission rate falls and the royalty rate increases. 
Those propositions allow us to return to the incentive conditions. Thus, suppose that the manager is friendlier to customers, which could generate more sales; in other words, the effect of the manager's effort on downstream sales $\beta$ increases, and hence principal should incentivize him through an increase in salary (commission rate). The same is true for the franchisee, except that he will be incentivized through a reduction in the royalty rate (share parameter). Now suppose that the franchisor's advertising effort is more effective in attracting customers, which would result in increased sales. In this case, franchisor would attempt to receive the most compensation, which is why the royalty rate increases and the commission rate decreases.

Proposition 3.7. There is an inverse relationship between the commission and royalty rates

$$
(r,(1-y)) \text {. }
$$

When the franchisor sets the royalty rate at the optimal level, which is in part determined by the commission rate, there is a direct relationship between the two rates. That is, there is an inverse relationship between the commission rate that the franchisor receives from the owned-unit and the royalty rate he receives from the franchised unit.

A similar result is obtained when the franchisor sets the commission rate at the optimal level, which is in part determined by the royalty rate. If the optimal $y^{*}$ is substituted into $r^{*}$, the commission rate will also depend on the importance of the franchisee's effort and vice-versa. Thus, a relationship exists between the two rates, as they are related to the same network. This result suggests that the units are complementary, which is consistent with Bai and Tao (2000).

\section{Conclusion}

Several theoretical economic models explain the existence of plural form distribution networks, and several models address the determination of the monetary provisions in the franchise contracts.

However, the previous literature failed to address the determination of the monetary contractual terms in a plural form system.

Our model provides an approach based on the agency theory, which accounts for risk aversion and incentive issues, to understand the mechanisms related to the determination of the royalty and commission rates in a mixed distribution chain.

The paper demonstrates that: when the franchisee's risk aversion increases, the royalty rate increases; when the manager's risk aversion increases, the commission rate falls; when the franchisor's risk aversion increases, the commission rate increases and the royalty rate falls; when the importance of the franchisee's effort in determining downstream sales increases, the royalty rate falls; when the importance of the manager's effort in determining downstream sales increases, the commission rate increases; when the importance of the principal's effort in determining downstream sales increases, the commission rate falls and the royalty rate increases; there is an inverse relationship between the rates set by the franchisor.

Even if our model improves the theoretical understanding of the determination of the monetary contractual terms in a plural form system, we think that numerous improvements could be included, since we first assume that each outlet faces the same environmental uncertainty. Second, we assume that the principal and each agent are characterized by constant risk aversion, which is identical for all actors. However, we know that each agent has a different level of risk aversion, for instance a franchisee would be less risk averse than a manager who receives a fixed wage each month, as the franchisee' income will depend on sales. That is, in the franchise system it is more risky to be a franchisee than a manager. Further theoretical research could 
address these problems and thereby provide further insights. In addition, our aim is test the predictions of the model using an econometric analysis of actual data. This would allow us to evaluate the effect of the risk aversion on the monetary clauses in franchise contracts. 


\section{Appendix 1: Nomenclature}

\begin{tabular}{|c|c|}
\hline$C E_{p}$ & Certainty equivalent of the franchisor \\
\hline$C E_{m}$ & Certainty equivalent of the manager \\
\hline$C E_{f}$ & Certainty equivalent of the franchisee \\
\hline$I_{p}$ & Franchisor's income \\
\hline$I_{m}$ & Manager's income \\
\hline$I_{f}$ & Franchisee's income \\
\hline$\varepsilon$ & $\begin{array}{l}\text { The profit function does not depend on } \\
\text { the agent's effort or the state of nature. This latter is } \\
\text { not controlled by the agent. }\end{array}$ \\
\hline$h()$. & Demand function \\
\hline$S$ & Sales \\
\hline$l$ & Price of good \\
\hline$R_{f}$ & Franchisee's risk aversion \\
\hline$R_{p}$ & Franchisor's risk aversion \\
\hline$R_{m}$ & Manager's risk aversion \\
\hline$F$ & Up-front fee \\
\hline$\alpha_{f}$ & Franchisee's risk aversion coefficient \\
\hline$\alpha_{p}$ & Franchisor's risk aversion coefficient \\
\hline$\alpha_{m}$ & Manager's risk aversion coefficient \\
\hline$r$ & Royalty rate \\
\hline$y$ & Commission rate \\
\hline$e_{f}$ & Franchisee's effort \\
\hline$e_{p}$ & Franchisor's effort \\
\hline$e_{m}$ & Manager's effort \\
\hline$C(e)$ & Effort in sales process \\
\hline$\theta_{y, r}^{2}$ & $\begin{array}{l}\text { Variance in income due to the state of nature in } \\
\text { the franchised unit }\end{array}$ \\
\hline$\delta$ & Effect of the franchisor's effort on downstream sales \\
\hline$W$ & Manager's wage \\
\hline$U$ & Manager's reservation utility \\
\hline$K$ & Franchisor's reservation utility \\
\hline$\lambda_{1,2}$ & Multiplier for the participation constraint \\
\hline$\lambda_{3,4,5}$ & Multiplier for the incentive compatibility constraint \\
\hline
\end{tabular}




\section{Appendix 2: Case 1}

The first-order conditions for the optimization ${ }^{11}$ are given by the following:

1. Lagrangian with respect to the wages:

$$
\lambda_{1}=1
$$

2. Lagrangian with respect to the up-front fee:

$$
\lambda_{2}=1
$$

3. Lagrangian with respect to $\lambda_{1,2}$ :

$$
\begin{gathered}
w+y\left(\beta e_{m}+\frac{\delta e_{p}}{2}\right)-\frac{e_{m}^{2}}{2}-\frac{\rho_{m}}{2} y^{2} \theta_{m}^{2}=U \\
(1-r)\left(\alpha e_{f}+\frac{\delta e_{p}}{2}\right)-F-\frac{e_{f}^{2}}{2}-\frac{\rho_{f}}{2}(1-r)^{2} \theta_{f}^{2}=K
\end{gathered}
$$

"Hence the franchisee's and manager's individual-rationality constraint must be binding. This implies that there are no rents left downstream" (Bhattacharyya S. and Lafontaine F. (1995)).

4. The Lagrangian with respect to the principal's effort indicates that:

$$
r \frac{\delta}{2}+(1-y) \frac{\delta}{2}-e_{p}-\lambda_{1}\left(-y \frac{\delta}{2}\right)-\lambda_{2}\left(-(1-r) \frac{\delta}{2}\right)=0
$$

Substituting equations (4.1) and (4.2) into (4.5), we have:

$$
\begin{gathered}
r \frac{\delta}{2}+\frac{\delta}{2}-y \frac{\delta}{2}-e_{p}+y \frac{\delta}{2}+\frac{\delta}{2}-\frac{\delta}{2} r=0 \\
\delta=e_{p}
\end{gathered}
$$

This expression indicates that the principal's effort is equal to effect of the franchisor's effort on downstream sales, as we are operating under symmetric information.

5. The Lagrangian with respect to the manager's effort indicates that:

$$
\beta-y \beta-\lambda_{1}\left(e_{m}-y \beta\right)=0
$$

Substituting equation (4.2) into (4.8), we have:

$$
\begin{gathered}
\beta-y \beta-e_{m}+y \beta=0 \\
e_{m}=\beta
\end{gathered}
$$

Similarly, the manager's effort is equal to his influence on downstream sales.

6. The Lagrangian with respect to the franchisee's effort indicates that:

\footnotetext{
${ }^{11}$ We assume that is sufficiently concave and that are sufficiently convex to ensure that the second-order conditions hold (Bhattacharyya S. and Lafontaine F., 1995).
} 


$$
r \alpha-\lambda_{2}\left(e_{f}-\alpha+r \alpha\right)=0
$$

Substituting equation (4.2) into (4.11), we have:

$$
\begin{gathered}
r \alpha-e_{f}-r \alpha+\alpha=0 \\
e_{f}=\alpha
\end{gathered}
$$

Similarly, the franchisee's effort is equal to his influence on downstream sales.

7. The Lagrangian with respect to the royalty rate indicates that:

$$
\alpha e_{f}+\frac{\delta e_{p}}{2}-\rho_{p} \theta_{f}^{2} r-\lambda_{2}\left(-\rho_{f} \theta_{f}^{2}+\rho_{f} \theta_{f}^{2} r+\alpha e_{f}+\frac{\delta e_{p}}{2}\right)
$$

Substituting equation (4.2) into (4.14), we have ${ }^{12}$ :

$$
\begin{gathered}
-\rho_{p} \theta_{f}^{2} r+\rho_{f} \theta_{f}^{2}-\rho_{f} \theta_{f}^{2} r \\
r^{*}=\frac{\rho_{f} \theta_{f}^{2}}{\rho_{p} \theta_{f}^{2}+\rho_{f} \theta_{f}^{2}}
\end{gathered}
$$

\begin{tabular}{|l|l|}
\hline Variable* & $\begin{array}{l}\text { Symmetric } \\
\text { Information }\end{array}$ \\
\hline$\rho_{f} \uparrow$ & $r \uparrow$ \\
\hline$\rho_{p} \uparrow$ & $r \downarrow$ \\
\hline
\end{tabular}

8. The Lagrangian with respect to the commission rate indicates that:

$$
-\beta e_{m}-\frac{\delta e_{p}}{2}+\rho_{p} \theta_{m}^{2}-\rho_{p} \theta_{m}^{2} y-\lambda_{1}\left(\rho_{m} \theta_{m}^{2} y-\beta e_{m}-\frac{\delta e_{p}}{2}\right)=0
$$

Substituting equation (4.1) into (4.17), we have ${ }^{13}$ :

$$
\begin{gathered}
\rho_{p} \theta_{m}^{2}-\rho_{p} \theta_{m}^{2} y-\rho_{m} \theta_{m}^{2} y=0 \\
y^{*}=\frac{\rho_{p} \theta_{m}^{2}}{\rho_{p} \theta_{m}^{2}+\rho_{m} \theta_{m}^{2}}
\end{gathered}
$$

\begin{tabular}{|l|l|}
\hline Variable* $^{*}$ & $\begin{array}{l}\text { Symmetric } \\
\text { Information }\end{array}$ \\
\hline$\rho_{m} \uparrow$ & $y \downarrow$ \\
\hline$\rho_{p} \uparrow$ & $y \uparrow$ \\
\hline
\end{tabular}

\footnotetext{
${ }^{12}$ The set of restrictions is convex, suggesting a maximum, which is verified using Matlab software.

${ }^{13}$ The set of restrictions is convex, suggesting a maximum, which is verified using Matlab software.
} 


\section{Appendix 3: Case 2}

The first-order conditions for the optimization ${ }^{14}$ are given by the following:

1. Lagrangian with respect to the wages:

$$
\lambda_{1}=1
$$

2. Lagrangian with respect to the up-front fee:

$$
\lambda_{2}=1
$$

3. Lagrangian with respect to $\lambda_{1,2,3,4,5}$ :

$$
\begin{gathered}
w+y\left(\beta e_{m}+\frac{\delta e_{p}}{2}\right)-\frac{e_{m}^{2}}{2}-\frac{\rho_{m}}{2} y^{2} \theta_{m}^{2}=U \\
(1-r)\left(\alpha e_{f}+\frac{\delta e_{p}}{2}\right)-F-\frac{e_{f}^{2}}{2}-\frac{\rho_{f}}{2}(1-r)^{2} \theta_{f}^{2}=K
\end{gathered}
$$

"Hence the franchisee's and manager's individual-rationality constraint must be binding. This implies that there are no rents left downstream" (Bhattacharyya S. and Lafontaine F. (1995)).

$$
\begin{gathered}
(r+(1-y)) \frac{\delta e_{p}}{2}=e_{p} \\
(1-r) \alpha=e_{f} \\
y \beta=e_{m}
\end{gathered}
$$

The effort provided by each agent and principal is equal to their incentives and the importance of their effort in determining downstream sales.

4. The Lagrangian with respect to the principal's effort indicates that:

$$
r \frac{\delta}{2}+(1-y) \frac{\delta}{2}-e_{p}-\lambda_{1}\left(-y \frac{\delta}{2}\right)-\lambda_{2}\left(-(1-r) \frac{\delta}{2}\right) \lambda_{3}=0
$$

Substituting equations (4.20) and (4.21) and (iii) into (4.27), we have:

$$
\lambda_{3}=\frac{\delta}{2}(y-r+1)
$$

We know that commission and royalty rates are less than 1 , and hence we can conclude that $\lambda_{3}$ is positive.

5. The Lagrangian with respect to the manager's effort indicates that:

$$
\beta-y \beta-\lambda_{1}\left(e_{m}-y \beta\right)-\lambda_{5}=0
$$

\footnotetext{
${ }^{14}$ We assume that is sufficiently concave and that are sufficiently convex to ensure that the second-order conditions hold (Bhattacharyya S. and Lafontaine F., 1995).
} 
Substituting equation (4.20) into (4.29), we have:

$$
\lambda_{5}=\beta(1-y)
$$

$\lambda_{5}$ is positive because the commission rate is less than 1.

6. The Lagrangian with respect to the franchisee's effort indicates that:

$$
r \alpha-\lambda_{2}\left(e_{f}-(1-r) \alpha\right)-\lambda_{4}=0
$$

Substituting equation (4.21) and (iv) into (4.31), we have:

$$
\lambda_{4}=r \alpha
$$

$\lambda_{4}$ is also positive.

7. The Lagrangian with respect to the royalty rate indicates that:

$$
\alpha e_{f}+\frac{\delta e_{p}}{2}-\rho_{p} \theta_{f}^{2} r-\lambda_{2}\left(-\rho_{f} \theta_{f}^{2}+\rho_{f} \theta_{f}^{2} r+\alpha e_{f}+\frac{\delta e_{p}}{2}\right)+\lambda_{3} \frac{\delta e_{p}}{2}-\lambda_{4} \alpha
$$

Substituting equation (4.21), (4.28) and (4.32) into (4.33), we have ${ }^{15}$ :

$$
\begin{gathered}
-4 \rho_{p} \theta_{f}^{2} r+4 \rho_{f} \theta_{f}^{2}+\delta^{2}(y-r+1)-4 r \alpha^{2} \\
r^{*}=\frac{4 \rho_{f} \theta_{f}^{2}+\delta^{2} y+\delta^{2}}{4 \rho_{p} \theta_{f}^{2}+4 \rho_{f} \theta_{f}^{2}+4 \alpha^{2}+\delta^{2}}
\end{gathered}
$$

\begin{tabular}{|l|l|}
\hline Variable* & $\begin{array}{l}\text { Asymmetric } \\
\text { Information }\end{array}$ \\
\hline$\rho_{f} \uparrow$ & $r \uparrow$ \\
\hline$\rho_{p} \uparrow$ & $r \downarrow$ \\
\hline$\delta \uparrow$ & $r \uparrow$ \\
\hline$\alpha \uparrow$ & $r \downarrow$ \\
\hline
\end{tabular}

8. The Lagrangian with respect to the commission rate indicates that:

$$
-\beta e_{m}-\frac{\delta e_{p}}{2}+\rho_{p} \theta_{m}^{2}-\rho_{p} \theta_{m}^{2} y-\lambda_{1}\left(\rho_{m} \theta_{m}^{2} y-\beta e_{m}-\frac{\delta e_{p}}{2}\right)-\lambda_{3} \frac{\delta}{2}+\lambda_{5} \beta=0
$$

Substituting equation (4.20), (4.28) and (4.30) into (4.36), we have ${ }^{16}$ :

$$
\begin{gathered}
4 \rho_{p} \theta_{m}^{2}-4 \rho_{p} \theta_{m}^{2} y-4 \rho_{m} \theta_{m}^{2} y-\delta^{2}(y-r+1)+4(1-y) \beta^{2}=0 \\
y^{*}=\frac{4 \rho_{p} \theta_{m}^{2}+r \delta^{2}-\delta^{2}+4 \beta^{2}}{4 \rho_{p} \theta_{m}^{2}+4 \rho_{m} \theta_{m}^{2}+\delta^{2}+4 \beta^{2}}
\end{gathered}
$$

\footnotetext{
${ }^{15}$ The set of restrictions is convex, suggesting a maximum, which is verified using Matlab software.

${ }^{16}$ The set of restrictions is convex, suggesting a maximum, which is verified using Matlab software.
} 


\begin{tabular}{|l|l|}
\hline \multicolumn{1}{|c|}{ Variable* $^{*}$} & $\begin{array}{l}\text { Asymmetric } \\
\text { Information }\end{array}$ \\
\hline$\rho_{m} \uparrow$ & $y \downarrow$ \\
\hline$\rho_{p} \uparrow$ & $y \uparrow$ \\
\hline$\beta \uparrow$ & $y \uparrow$ \\
\hline$\delta \uparrow$ & $y \downarrow$ \\
\hline
\end{tabular}




\section{Appendix 4: Covariance}

We need to know the covariance value. According to Lafontaine and Blair (2005):

$$
\frac{\rho_{f}}{2} \operatorname{Var}\left(\text { franchise }{ }^{\prime} \text { sincome }\right)=\frac{\rho_{f}}{2} \operatorname{Var}\left((1-r) \theta_{f}\right)=\frac{\rho_{f} \theta_{f}^{2}}{2}(1-r)^{2}
$$

However, the variance definition indicates that:

$$
\operatorname{Var}(X)=E\left[(X-\mu)^{2}\right]=E\left(X^{2}\right)-\mu^{2}
$$

$X$ is a random variable with average $\mu=E(X)$. Lafontaine and Blair (2005) assumed that this variation is nearly 0 . That is why they set $(1-r)^{2}$.

The covariance definition indicates:

$$
\operatorname{Cov}(X Y)=E[(X-E(X))(Y-E(Y))]
$$

$X$ and $Y$ are random variables. Following this analogy, we can easily determine the covariance, which could be defined as:

$$
\operatorname{Cov}\left(\left(\theta_{m}(1-y)\right),\left(\theta_{f} r\right)\right)=\theta_{f} \theta_{m} r(1-y)
$$




\section{Appendix 5: Case 3}

The first-order conditions for the optimization ${ }^{17}$ the remain identical to those in the case without the covariance between $r$ and $y$ :

$$
\begin{gathered}
\lambda_{1}=1 \\
\lambda_{2}=1 \\
\lambda_{3}=\frac{\delta}{2}(y-r+1) \\
\lambda_{4}=r \alpha \\
\lambda_{5}=\beta(1-y)
\end{gathered}
$$

1. The Lagrangian with respect to the royalty rate indicates that:

$$
\alpha e_{f}+\frac{\delta e_{p}}{2}-\rho_{p} \theta_{f}^{2} r-\rho_{p} \theta_{f} \theta_{m}(1-y)-\lambda_{2}\left(-\rho_{f} \theta_{f}^{2}+\rho_{f} \theta_{f}^{2} r+\alpha e_{f}+\frac{\delta e_{p}}{2}\right)+\lambda_{3} \frac{\delta}{2}-\lambda_{4} \alpha
$$

Substituting equation (4.44), (4.45) and (4.46) into (4.48), we have ${ }^{18}$ :

$$
\begin{gathered}
-4 \rho_{p} \theta_{f}^{2} r-4 \rho_{p} \theta_{f} \theta_{m}(1-y)+4 \rho_{f} \theta_{f}^{2}-4 \rho_{f} \theta_{f}^{2} r+\delta^{2}(y-r+1)-4 r \alpha^{2} \\
r^{*}=\frac{4 \rho_{f} \theta_{f}^{2}+\delta^{2} y+\delta^{2}-4 \rho_{p} \theta_{f} \theta_{m}+4 \rho_{p} \theta_{f} \theta_{m} y}{4 \rho_{p} \theta_{f}^{2}+4 \rho_{f} \theta_{f}^{2}+4 \alpha^{2}+\delta^{2}}
\end{gathered}
$$

\begin{tabular}{|l|l|}
\hline Variable* & $\begin{array}{l}\text { Asymmetric } \\
\text { Information }\end{array}$ \\
\hline$\rho_{f} \uparrow$ & $r \uparrow$ \\
\hline$\rho_{p} \uparrow$ & $r \downarrow$ \\
\hline$\delta \uparrow$ & $r \uparrow$ \\
\hline$\alpha \uparrow$ & $r \downarrow$ \\
\hline$y \uparrow$ & $r \uparrow$ \\
\hline
\end{tabular}

2. The Lagrangian with respect to the commission rate indicates that:

$$
-\beta e_{m}-\frac{\delta e_{p}}{2}+\rho_{p} \theta_{m}^{2}-\rho_{p} \theta_{m}^{2} y+\rho_{p} \theta_{f} \theta_{m} r-\lambda_{1}\left(\rho_{m} \theta_{m}^{2} y-\beta e_{m}-\frac{\delta e_{p}}{2}\right)-\lambda_{3} \frac{\delta}{2}+\lambda_{5} \beta=0
$$

\footnotetext{
${ }^{17} \mathrm{We}$ assume that is sufficiently concave and that are sufficiently convex to ensure that the second-order conditions hold (Bhattacharyya S. and Lafontaine F., 1995).

${ }^{18}$ The set of restrictions is convex, suggesting a maximum, which is verified using Matlab software.
} 
Substituting equation (4.43), (4.45) and (4.47) into (4.51), we have ${ }^{19}$ :

$$
\begin{gathered}
4 \rho_{p} \theta_{m}^{2}-4 \rho_{p} \theta_{m}^{2} y-4 \rho_{m} \theta_{m}^{2} y+4 \rho_{p} \theta_{f} \theta_{m} r-\delta^{2}(y-r+1)+4(1-y) \beta^{2}=0 \\
y^{*}=\frac{4 \rho_{p} \theta_{m}^{2}+4 \rho_{p} \theta_{f} \theta_{m} r+r \delta^{2}-\delta^{2}+4 \beta^{2}}{4 \rho_{p} \theta_{m}^{2}+4 \rho_{m} \theta_{m}^{2}+\delta^{2}+4 \beta^{2}}
\end{gathered}
$$

\begin{tabular}{|l|l|}
\hline Variable* & $\begin{array}{l}\text { Asymmetric } \\
\text { Information }\end{array}$ \\
\hline$\rho_{m} \uparrow$ & $y \downarrow$ \\
\hline$\rho_{p} \uparrow$ & $y \uparrow$ \\
\hline$\beta \uparrow$ & $y \uparrow$ \\
\hline$\delta \uparrow$ & $y \downarrow$ \\
\hline$r \uparrow$ & $y \uparrow$ \\
\hline
\end{tabular}

${ }^{19}$ The set of restrictions is convex, suggesting a maximum, which is verified using Matlab software. 


\section{References}

[1] Alon, I. (2000), The use of franchising by U.S.-based retailers, Journal of Small Business Management, 39, 111-122.

[2] Bai, C. and Tao, Z. (2000). Contract Mixing In Franchising as a Mechanism for Public-Good Provision, Joumal of Economics and Management Strategy, 9(1), 85-113.

[3] Bhattacharyya, S. and Lafontaine, F. (1995). Double-Sided Moral Hazard and the Nature of Share Contracts, RAND Journal of Economics, 26(4), 761-781.

[4] Bradach J. (1997). Using the Plural Form in the Management of Restaurant Chains. Administrative Science Quarterly, 42, 276-303.

[5] Brazilian Franchising Association, Guia de Franquicias. http://www.portaldofranchising.com.br/site/content/home/, 2010. Access on July 19 2012.

[6] Brazilian Franchising Association, Economic impact in Brazil reaches new heights in 2010. Economic impact in Brazil reaches new heights in 2010 http://www.franchise.org/uploadedFiles/Economic/20Impact/20in/20Brazil/20Re Access on July 302012.

[7] Brickley, J. (2002). Royalty Rates and Upfront Fees in Share Contracts: Evidence from Franchising, Journal of Law, Economics and Organization, 18, 511-535.

[8] Brickley, J. Dark, F. (1987). The Choice of Organizational Form: The Case of Franchising, Journal of Financial Economics, 18, 401-420

[9] Brickley, J., Dark, F., and Weisbach, M. (1991). The Economic Effect of Franchise Termination Laws, Journal of Law and Economics, 34, 101-132.

[10] Bürkle, T. and Posselt, T. (2008). Franchising as a plural system: A risk-based explanation, Journal of Retailing, 84, 39-47

[11] Castrogiovanni, G., Combs, J. and Justis, R. (2006). Shifting Imperatives: An Integrative Resource Scarcity and Agency Reasons for Franchising, Entrepreneurship Theory and Practice, 30, 23-40

[12] Dant, R. and Windsperger, J. (2006), Contractibility and ownership redirection in franchising: A property rights view. Journal of Retailing, 82, 259-272.

[13] Chirico, F., Ireland, D. and Sirmon, D. (2011). Franchising and the Family Firm: Creating Unique Sources of Advantage Through 'Familiness'. Entrepreneurship Theory and Practice, $35(3), 483-501$

[14] Etro, F. (2011). Endogenous market structures and contract theory: Delegation, principalagent contracts, screening, franchising and tying, European Economic Review, 55, 463-479.

[15] French Franchising Federation, Toute la France 2012. N ISSN 1956-9286

[16] Front Consulting Group and Cámara Venezolana de Franquicias-Profranquicias, Franquiguia 2012. Acces on 23 July 2012. 
[17] Front Consulting Group and Cámara Venezolana de Franquicias-Profranquicias, Estadisticas de las Franquicias en Venezuela, 2011. Acces on 23 July 2012.

[18] Gallini, N. and Lutz, N. (1992). Dual Distribution and Royalty Fees in Franchising, Journal of Law, Economics $\&$ Organization, 8, 471-501

[19] Harrigan, K. (1984). Formulating vertical integration strategies, Academy of Management Review, 9, 638-652.

[20] Hemplemann, B. (2006). Optimal franchise contracts with private cost information. International Journal of Industrial Organization, 24, 449-465

[21] Hendrikse, G. and Jiang, T. (2011). An Incomplete Contracting Model of Dual Distribution in Franchising, Journal of Retailing, 87(3), 332-344.

[22] Hunt, S. (1973). The Trend Toward Company-Operated Units in Franchise Chains, Journal of Retailing, 49, 3-12.

[23] Lafontaine, F. and Shaw, K. (2005). Targeting managerial control: evidence from franchising, RAND Journal of Economics, 36, 131-150

[24] Lafontaine, F. and Blair, R. (2005). The Economics of Franchising, Cambridge.

[25] Lafontaine, F. and Slade, M. (2010). Transaction Cost Economics and Vertical Market Restrictions; The Evidence, Antitrust Bulletin, 55 (3), 587-611

[26] Lafontaine, F. and Slade, M. (1998). Incentive and the Franchise Decision, in Advances in Business Applications of Game Theory, chapter 2

[27] Lafontaine, F. and Kaufmann, P. (1994). The Evolution of Ownership Patterns in Franchise Systems, Journal of Retailing, 70, 97-113

[28] Lafontaine, F. (1992). Agency Theory and Franchising; Some Empirical Results, RAND Journal of Economics, 23, 263-283

[29] Lewis, R. (2002). Learning by doing and dynamic regulation, RAND Journal of Economics, $33(1), 22-36$

[30] Macho-Stadler, I. and Pérez-Castrillo, D. (2001). An Introduction to the Economics of Information: Incentives and Contracts. Oxford University Press, second ed.

[31] Mexican Association of Franchises, Estadisticas AMF 2012, https://docs.google.com/viewer?url=http://franquiciasdemexico.org/docs/Estadistica s2012.pdf\&chrome=true. Acces on 20 July 2012

[32] Milgrom, P. and Roberts, J. (1992). Economics, Organization and Management. PrenticeHall International, Inc. First edition. IS: 0132246503

[33] Nair, S., Tikoo, S. and Liu, S. (2009). Valuing exclusivity from encroachment in franchising, Journal of Retailing, 85(2), 206-210

[34] Oxenfeldt, A. and Kelly, A. (1969). Will successful franchise systems eventually become wholly-owned chains? Journal of Retailing, 44, 4, 69-83. 
[35] Pénard, T., Raynaud, E. and Saussier, S. (2011). Monitoring Policy and Organizational Forms in Franchised Chains, International Journal of the Economics of Business, 18, 399417.

[36] PricewaterhouseCoopers, Franchise business economic outlook: 2011. http://www.franchise.org/uploadedFiles/Franchise/20Business/20Outlook/20Report/2020 11/20final.pdf, 2011. Acces on 13 July 2012.

[37] Rey, P. and Tirole, J. (1986). The Logical of Vertical Restraints, American Economic Review, 76 (5), 921-939.

[38] The U.S. Commercial Service, Venezuela-franchise industry. http://www.franchise.org/uploadedFiles/Franchise_Industry/International_Development/ Resources/VenezuelaFranchise/20Report/ 20Final.pdf, 2008. Acces on 23 July 2012.

[39] The U.S. Commercial Service, CS Mexico Market Report Franchise Services Sector in Mexico, http://www.franchise.org/uploadedFiles/Franchise_Industry/International_Develop ment/Country_Profiles/Mexico_Franchising/20in/20Secondary/20Markets_April/20 2009.pdf. Access on 02 August 2012.

[40] Tracey, P. and Jarvis, O. (2007). Toward a Theory of Social Venture Franchising, European Economic Review, 31(5), 667-685.

[41] Vázquez, L. (2005). Up-front fees and ongoing variable payments as substitutes: an agency perspective. Review of Industrial Organization, 16, 445-460. 